\title{
A consideration for our daily work
}

Author(s):

Nicholas Brennecke, $\mathrm{MD}^{1}$

Equal Author Contributions:

I wrote the entire work.

Neurology ${ }^{\circledR}$ Published Ahead of Print articles have been peer reviewed and accepted for publication. This manuscript will be published in its final form after copyediting, page composition, and review of proofs. Errors that could affect the content may be corrected during these processes. 


\section{Corresponding Author:}

Nicholas Brennecke

nicholas.brennecke@uhhospitals.org

Affiliation Information for All Authors: 1. Department of Neurology, Case Western Reserve University \& University Hospital Cleveland Medical Center

\section{Contributions:}

Nicholas Brennecke: Additional contributions: I wrote the entire work.

Number of characters in title: 34

Abstract Word count: 0

Word count of main text: 69

References: 0

Figures: 0

Tables: 0

Search Terms: [ 14 ] All Clinical Neurology

Acknowledgements: With thanks to my father, who has always modeled deep compassion for those around him, and who first encouraged me to go into medicine.

Study Funding: The authors report no targeted funding

Disclosures: The author reports no disclosures relevant to the manuscript.. 
Workup is benign.

Parents breathe. Baby kicks, coos.

A febrile seizure.

With time, across space,

A young mother is stricken.

Demyelination.

Slow, humbled, genteel.

An old athlete stoops, deprived

Substantia nigra.

Right? Left? Which is which?

"Grandpop" searches his hands, sans

Angular gyrus.

"Sue, it's Jim... it's me."

Eyes meet briefly in love past

Plaques and tau tangles.

In analyzing

May we all ever see the

Human before us. 


\section{Neurology}

A consideration for our daily work

Nicholas Brennecke

Neurology published online January 31, 2022

DOI 10.1212/WNL.0000000000200037

\section{This information is current as of January 31, 2022}

Updated Information \&

Services

Subspecialty Collections

Permissions \& Licensing

Reprints including high resolution figures, can be found at: http://n.neurology.org/content/early/2022/01/31/WNL.0000000000200 037.citation.full

This article, along with others on similar topics, appears in the following collection(s):

\section{All Clinical Neurology}

http://n.neurology.org/cgi/collection/all_clinical_neurology

Information about reproducing this article in parts (figures,tables) or in its entirety can be found online at:

http://www.neurology.org/about/about_the_journal\#permissions

Information about ordering reprints can be found online:

http://n.neurology.org/subscribers/advertise

Neurology $®$ is the official journal of the American Academy of Neurology. Published continuously since 1951, it is now a weekly with 48 issues per year. Copyright (C) 2022 American Academy of Neurology. All rights reserved. Print ISSN: 0028-3878. Online ISSN: 1526-632X.

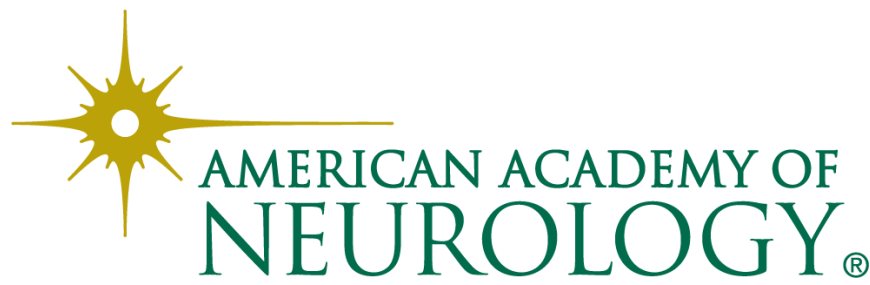

